\title{
Chemical characterization and oxidative stability of olive oils extracted from olive trees of Southern Brazil
}

\author{
Mariângela Hoffmann Bruscatto(1), Rui Carlos Zambiazi(2), Michele Crizel-Cardoso(1), Clarisse Maria Sartori \\ Piatnicki(3), Carla Rosane Barboza Mendonça ${ }^{(2)}$, Fabiana Lemos Goularte Dutra ${ }^{(1)}$ and Enilton Fick Coutinho ${ }^{(4)}$ \\ (1)Universidade Federal de Pelotas (Ufpel), Departamento de Ciência e Tecnologia Agroindustrial, Caixa Postal 354, CEP 96010-900 Pelotas, \\ RS, Brazil. E-mail: marianhbruscatto@gmail.com, mi.crizel@hotmail.com, fgoularte@hotmail.com ${ }^{(2)}$ Ufpel, Centro de Ciências Químicas, \\ Farmacêuticas e de Alimentos, Caixa Postal354, CEP 96010-900 Pelotas, RS, Brazil.E-mail:zambiazi@gmail.com, carlaufpel@hotmail.com \\ (3)Universidade Federal do Rio Grande do Sul, Instituto de Química Inorgânica, Campus do Vale, Avenida Bento Gonçalves, no 9.500, \\ Agronomia, CEP 91701-970 Porto Alegre, RS, Brazil. E-mail: clarisse@iq.ufrgs.br ${ }^{(4)}$ Embrapa Clima Temperado, Caixa Postal 403, \\ CEP 96010-971 Pelotas, RS, Brazil. E-mail: enilton.coutinho@embrapa.br
}

\begin{abstract}
The objective of this work was to characterize the chemical composition of olive (Olea europaea) oils produced in Southern of Brazil and correlate it with oxidative stability. Olive oils from the Arbequina, Coratina, Frantoio and Koroneiki cultivars were evaluated. A completely randomized experimental design was used, in a uniform arrangement, with three replicates. Acidity value, peroxide index, specific absorption, tocopherol content, phenolic compound content, carotenoid content, chlorophyll content, fatty acid profile, and oxidative stability were determined. The oils from the Coratina and Frantoio cultivars were classified as extra virgin-oils. The olive oil from the Coratina cultivar showed the highest levels of pigments, followed by the oil from Koroneiki. The oil from the Coratina cultivar also presents higher contents of phenolic compounds $\left(1,725.5 \mathrm{mg} \mathrm{kg}^{-1}\right)$ and tocopherols $\left(437.8 \mathrm{mg} \mathrm{kg}^{-1}\right)$. The major fatty acid in all samples is oleic acid.
\end{abstract}

Index terms: Olea europaea, bioactive compounds, fatty acids, induction period, olive, quality parameters.

\section{Caracterização química e estabilidade oxidativa de azeites extraídos de oliveiras do Sul do Brasil}

\begin{abstract}
Resumo - O objetivo deste trabalho foi caracterizar a composição química de azeites de oliva (Olea europaea) produzidos no Sul do Brasil e correlacioná-la com a estabilidade oxidativa. Foram avaliados azeites das cultivares Arbequina, Coratina, Frantoio e Koroneiki. Utilizou-se o delineamento experimental inteiramente casualizado, em arranjo unifatorial, com três repetições. Foram determinados índice de acidez, índice de peróxidos, absorção específica, teor de tocoferois, teor de compostos fenólicos, teor de carotenoides, teor de clorofilas, perfil de ácidos graxos e estabilidade oxidativa. Os azeites provenientes das cultivares Coratina e Frantoio foram classificados como extra virgens. O azeite da cultivar Coratina apresentou maiores teores de pigmentos, seguido pelo da cultivar Koroneiki. A cultivar Coratina ainda apresenta maiores conteúdos de compostos fenólicos $\left(1.725,5 \mathrm{mg} \mathrm{kg}^{-1}\right)$ e de tocoferois $\left(437,8 \mathrm{mg} \mathrm{kg}^{-1}\right)$. O ácido graxo majoritário em todas as amostras é o oleico.
\end{abstract}

Termos para indexação: Olea europaea, compostos bioativos, ácidos graxos, período de indução, azeitona, parâmetros de qualidade.

\section{Introduction}

The consumption of extra-virgin olive oil has increased significantly due to its unique sensory characteristics and health benefits. Typical aroma, flavor, color, and functional properties allow distinguishing olive oil from other edible vegetable oils (Fadda et al., 2012).

Olive oil, as well as other oils and fats, besides contributing to the quality of certain foodstuffs, provides nutritional value as a good source of metabolic energy, as well as essential linoleic and $\alpha$-linolenic fatty acids. Its composition is characterized by a high content of a monounsaturated fatty acid, the oleic acid (Krichene et al., 2010), associated with high levels of bioactive compounds such as tocopherols, phenolic compounds, phytosterol (mainly $\beta$-sitosterol) and pigments (chlorophylls and carotenoids), which contribute to its sensory characteristics, as well as the 
oxidative stability (Allalout et al., 2009; Krichene et al., 2010; Fregapane \& Salvador, 2013). Important functions are also assigned to bioactive compounds, such as the participation in the prevention of cardiovascular diseases, cancers, degenerative diseases, and obesity (Fadda et al., 2012; Cicerale et al., 2013). However, olive oil is quite susceptible to lipid oxidation, a spontaneous and unavoidable phenomenon, with direct implication on the commercial value of the oils, either in pure oil or in products containing oil in their formulation, as food, cosmetics, and medicines (Silva et al., 1999).

Scientific interest in olive cultivation in the state of Rio Grande do Sul, Brazil, is due to suitable characteristics for olive oil production, especially from the Coratina, Frantoio, and Koroneiki cultivars, which have shown high and constant fruit productivity (Coutinho et al., 2009; Servili, 2015). Arbequina, one of the most suitable cultivars for olive production, presents good adaptation to Brazilian soil and exhibits vegetative vigor, precocity, and high yielding capacity (Coutinho et al., 2009). Therefore, quality, chemical composition, and stability of oils produced in Southern Brazil should be investigated.

The objective of this work was to characterize the chemical composition of olive oils produced in Southern of Brazil and correlate it with oxidative stability.

\section{Materials and Methods}

Experiments were conducted in the chromatography laboratory at Universidade Federal de Pelotas, located in the municipality of Capão do Leão, state of Rio Grande do Sul, Brazil. Olive oil samples were obtained from the Arbequina, Coratina, Frantoio, and Koroneiki cultivars during the 2013/2014 harvest, from adult plants of Olea europaea L., from the experimental unit of Embrapa Clima Temperado, located in the municipality of Pelotas, Rio Grande do Sul, Brazil $\left(52^{\circ} 21^{\prime} \mathrm{W}, 31^{\circ} 52^{\prime} \mathrm{S}\right.$, at an altitude of $\left.224 \mathrm{~m}\right)$. The soil of the region is classified as Luvissolo Hipocrômico órtico típico (Alfisols), a shallow clayey soil (Santos et al., 2006). The climate is characterized as humid with hot summers, according to the Köppen \& Geiger classification system (1928) with an annual average temperature of $18.4^{\circ} \mathrm{C}$ and rainfall of $1,582 \mathrm{~mm}$.

Oil extraction was performed by fruit rupture and centrifugation using the Abencor system, consisting of a MM-100 mill, a TB 100 thermobeater, and a CF-100 centrifuge (MC2, Ingenieria y Systemas, Sevilla, Spain) with subsequent decantation and filtration. Samples were packed in amber glasses and kept frozen at $-80^{\circ} \mathrm{C}$ in an ultra freezer (Ilshin Cab, Co., Ltd., Tongjin-eup, South Korea) until the analysis was initiated. The olive fruits used in the oil extraction were obtained from a completely randomized experimental design, in a factorial arrangement, with three replicates.

The reagents and solvents used in the experiment were ethyl ether, ethyl alcohol, potassium hydroxide, acetic acid, sulfuric acid, chloroform, sodium thiosulfate, hexane, methanol, sodium carbonate, Folin-Ciocalteu reagent, phenolphthalein indicator, potassium iodide, and gallic acid of analytical grade; isopropanol, isooctane, methanol, ethanol, and n-hexane (HPLC grade) were purchased from SigmaAldrich (São Paulo, Brazil) and Synth (Diadema, Brazil).

The fatty acid methyl ester mix containing caproic, caprylic, caproleic, lauric, dodecenoic, myristic, myristoleic, palmitic, palmitoleic, margaric, stearic, oleic, linoleic, linolenic, arachidic, gadoleic, eicosadienoic, eicosatrienoic, tetraenoic, lignoceric, and nervonic acids were purchased from Sigma Chemicals Co. (St. Louis, USA). The $\delta$ and $\gamma$-tocopherol standards (90 and $\geq 96 \%$ purity, respectively) were obtained from Sigma Co. (St. Louis, USA), and $\alpha$-tocopherol (99\% purity) from Merck (Darmstadt, Germany).

The acidity and peroxide value of the samples were determined respectively, according to the America Oil Chemists' Society (AOCS) methods Ca 5a - 40 (Firestone, 1998) and Cd 8-53 (Firestone, 1998). Specific absorption was measured at 232 and $270 \mathrm{~nm}$ $\left(\mathrm{K}_{232}\right.$ and $\left.\mathrm{K}_{270}\right)$ according to the method recommended by International Olive Council (IOOC) (2010), and tocopherol content was determined according to the method described by Pestana et al. (2008), with minor modifications. Approximately $0.250 \mathrm{mg}$ olive oil was diluted in isopropanol (high-performance liquid chromatography grade) up to $5 \mathrm{~mL}$ and the mixture was centrifuged for $6 \mathrm{~min}$ at $9,000 \mathrm{~g}$ in a microcentrifuge (NT800 Nova Técnica, Piracicaba, SP, Brazil). The organic phase was transferred to a $1.5-\mathrm{mL}$ vial and samples between 10 to $20 \mu \mathrm{L}$ were analysed using the high-performance liquid chromatography system (Shimadzu, Kyoto, Japan), 
consisting of the LC-10ATVP solvent mixing module, FCV-10ALVP degasser, DGU-14A reodine pump, SCL-10AVP system control, CTO-10ASVP column oven, and SIL-10AF automatic sampler. Tocopherol separation was performed using the Shimadzu reverse phase analytical column, Shim-Pack CLC-ODS (3.9 $\mathrm{cm} \times 150 \mathrm{~mm} \times 4 \mu \mathrm{m}$ ), having octadecyl groups as stationary phase, and a fluorescence detector with 290 and $330 \mathrm{~nm}$ of excitation and emission wavelength, respectively. Data were acquired and processed using the Class-VP software (Shimadzu, Kyoto, Japan). A mixture of acetonitrile: methanol: isopropanol in the ratio of 50:40:10 (v/v/v) was used as the starting mobile phase for $10 \mathrm{~min}$, changing linearly at $1 \mathrm{~mL} \mathrm{~min}{ }^{-1}$ constant flow to acetonitrile: methanol: isopropanol 30: $65: 5,(\mathrm{v} / \mathrm{v} / \mathrm{v})$ up to $12 \mathrm{~min}$, and returning linearly to the initial mobile phase up to $15 \mathrm{~min}$ of analysis.

The identification and quantification of tocopherols were performed using external calibration curves of $(\beta+\gamma)$ - and $\delta$-tocopherol, and the results were expressed as milligrams of tocopherol per $100 \mathrm{~g}$ of sample.

The extration of phenolic compounds followed the method described by Montedoro et al. (1992), with modifications. An oil sample of $2.5 \mathrm{~g}$ was mixed with 2.0 $\mathrm{mL}$ methanol: water (70:30) mixture and $2 \mathrm{~mL}$ hexane, subjected to vigorous stirring for $1 \mathrm{~min}$, followed by continuous agitation for $20 \mathrm{~min}$, and centrifugation at $7,000 \mathrm{~g}$ at $4^{\circ} \mathrm{C}$ for $10 \mathrm{~min}$ in the 5430R microcentrifuge (Eppendorf Hamburg, Germany). The hydroalcoholic phase was collected and centrifuged again at 7,000 $g$ at $4^{\circ} \mathrm{C}$ for $4 \mathrm{~min}$, transferred to a $2-\mathrm{mL}$ volumetric flask, and the volume completed with a methanol: water (70:30) mixture. Total phenolic compounds were determined, as described by Gambacorta et al. (2010), by mixing $100 \mu \mathrm{L}$ of the hydroalcoholic extract with $100 \mu \mathrm{L}$ of the Folin-Ciocalteu reagent at $2 \mathrm{~mol} \mathrm{~L}^{-1}$ in a falcon tube and, after $4 \mathrm{~min}$, adding $800 \mu \mathrm{L} \mathrm{5 \%}$ sodium carbonate. The mixture was kept in a water bath for $20 \mathrm{~min}$ at $40^{\circ} \mathrm{C}$. Samples were subjected to absorbance measurements at $750 \mathrm{~nm}$ in $6705 \mathrm{UV} / \mathrm{VIS}$ spectrophotometer (Jenway, Staffordshire, UK). For total phenolic compound quantification, a gallic acid standard curve was constructed, with readings at 750 $\mathrm{nm}$. The results were expressed as $\mathrm{mg} \mathrm{kg}^{-1}$ of gallic acid.

The carotenoid content was determined as described by Rodrigues-Amaya (2001), with readings at $450 \mathrm{~nm}$. The results were expressed as $\mathrm{mg} \mathrm{kg}^{-1} \beta$-carotene.
Total chlorophyll was determined at 630,670 , and $710 \mathrm{~nm}$ using the Cc 13d-55 methodology of AOCS (Firestone, 1998). For both analyses, a blend of isooctane: ethanol (3:1) was used as a reference, and the results were expressed as $\mathrm{mg} \mathrm{kg}^{-1}$. The both readings were performed on $6705 \mathrm{UV} / \mathrm{VIS}$ spectrophotometer (Jenway, Staffordshire, UK).

The olive oil samples were derivatized according Hartmann \& Lago (1973). Fatty acids were quantified in a gas chromatograph (Perkin Elmer Clarus 500, Shelton, USA), fitted with a FID detector, using a polyethylene glycol ID Carbowax 20M column $(0.25 \mu \mathrm{m}, 30 \mathrm{~m} \times 0.25 \mathrm{~mm})$. The temperature gradient was maintained at $90^{\circ} \mathrm{C}$ for $1 \mathrm{~min}$, increased at a $12^{\circ} \mathrm{C} \mathrm{min}^{-1}$ rate up to $160^{\circ} \mathrm{C}$ for $3.5 \mathrm{~min}$, then increased at a rate of $1.2^{\circ} \mathrm{C} \mathrm{min}^{-1}$ up to $190^{\circ} \mathrm{C}$, with a linear increase of $15^{\circ} \mathrm{C} \mathrm{min}-1$ up to $230^{\circ} \mathrm{C}$ for $15 \mathrm{~min}$. The injector and detector temperatures were maintained at $250^{\circ} \mathrm{C}$. Nitrogen at a rate of $1.5 \mathrm{~mL} \mathrm{~min}^{-1}$ was used as carrier gas (Zambiazi, 1997). Fatty acid methyl esters were identified by comparison with retention times of reference standards, and results were expressed as relative fatty acid percentage.

Oxidative stability was determined in the oil samples in the 743 Rancimat (Metrohm, Herisau, Switzerland) at $110^{\circ} \mathrm{C}$, at an inflation rate of $10 \mathrm{~L} \mathrm{~h}^{-1}$, according to EN ISO14112 (CEN, 2003).

Data were analyzed for normality by the ShapiroWilk test, homoscedasticity by the Hartley test, and residue independence by the graphic analysis. Subsequently, data were subjected to the analysis of variance through the F-test, at $5 \%$ probability. The effects of cultivars were compared by Tukey's test, at $5 \%$ probability, and correlations between dependent variables were analyzed using Pearson's correlation coefficient (SAS Institute Inc., Cary, NC).

\section{Results and Discussion}

Differences were observed in acidity values, except for the oils from the Coratina and Koroneiki cultivars (Table 1). In addition, only the oil from the Arbequina cultivar was not in line with the established legislation standards for extra-virgin olive oil $(0.8 \%)$, and it was classified as lampante virgin olive oil because it features acidity higher than 2\% (Brasil, 2012).

Several factors can lead to high acidity content, including harvesting process, fruit maturation index,

Pesq. agropec. bras., Brasília, v.52, n.12, p.1231-1240, dez. 2017 DOI: $10.1590 / \mathrm{S} 0100-204 \mathrm{X} 2017001200012$ 
olive quality, storage, and oil extraction. According to Cardoso et al. (2010), storage and oil extraction should not exceed 4 hours. The authors found high acidity content at the end of harvest, with values of 2.2 and $3.6 \%$, respectively, in the Ascolano and Negroa cultivars. The high acidity may have been due to the injury in fruits and time of exposure of the olives at room temperature, favoring enzyme activity, and increasing acidity values.

Peroxide values of olive oils from the Coratina and Frantoio cultivars were within the limits allowed for the classification of extra-virgin olive oil, according to Brasil (2012) and IOOC (2012). The other samples presented values above the limits established for extra-virgin and virgin olive oils. These results were probably due to the longer exposure time of the fruits before oil extraction or the greater injury between harvest and processing. Cardoso et al. (2010) also found high peroxide values in the oil from the Negroa olive cultivar (25.5\%), similar to the one found in oil from the Koroneiki cultivar.

Oils from the Coratina and Frantoio cultivars presented specific absorption coefficients $\left(\mathrm{K}_{270}\right)$ in accordance with the extra-virgin oil classification
(Table 1). For the other samples, the specific absorption coefficients $\mathrm{K}_{232}$ were within the limit for classification of extra-virgin olive oil. As the process of obtaining the oil was the same for all cultivars, it is assumed that differences in this parameter may be related to the characteristics of each cultivar. Dabbou et al. (2010) reported similar results to those obtained in this study for the oils from the Arbequina and Koroneiki cultivars.

Oil from the Coratina cultivar stood out due to the highest tocopherol content, with $\alpha$-tocopherol as the major compound in all oils (Table 2). Separation of $\gamma$ and $\beta$-tocopherol was not possible by the reverse phase column (Figure 1), so that results were expressed as the sum of both compounds.

Oils of the Arbequina and Frantoio cultivars presented lower tocopherol content, which varies according to the cultivar (Table 2). It should be noted that this compound plays an important role in the olive oil stability (Allouche et al., 2007). This variation is confirmed in the literature, with reports of $\alpha$-tocopherol content in virgin olive oil between 100 and $460 \mathrm{mg} \mathrm{kg}^{-1}$, representing $96 \%$ of total tocopherols

Table 1. Mean \pm standard deviation of quality indexes of olive (Olea europaea) oils from Arbequina, Coratina, Frantoio, and Koroneiki cultivars ${ }^{(1)}$.

\begin{tabular}{|c|c|c|c|c|}
\hline Cultivar & $\begin{array}{c}\text { Free acidity } \\
\text { (g 100 } \mathrm{g}^{-1} \text { oleic acid) }\end{array}$ & $\begin{array}{c}\text { Peroxide } \\
\left(\text { meq g kg-1 } \mathrm{O}_{2} \text { ) }\right.\end{array}$ & $\begin{array}{l}\mathrm{K}_{232} \\
(\mathrm{~nm}) \\
\end{array}$ & $\begin{array}{l}\mathrm{K}_{270} \\
(\mathrm{~nm})\end{array}$ \\
\hline Arbequina & $2.22 \pm 0.01 \mathrm{a}$ & $36.23 \pm 1.14 \mathrm{a}$ & $2.70 \pm 0.01 \mathrm{a}$ & $0.22 \pm 0.02 \mathrm{a}$ \\
\hline Coratina & $0.49 \pm 0.01 \mathrm{c}$ & $11.20 \pm 1.20 \mathrm{c}$ & $1.71 \pm 0.03 \mathrm{~d}$ & $0.15 \pm 0.02 \mathrm{~b}$ \\
\hline Frantoio & $0.79 \pm 0.03 b$ & $13.91 \pm 1.18 \mathrm{c}$ & $2.03 \pm 0.01 \mathrm{~b}$ & $0.14 \pm 0.01 \mathrm{~b}$ \\
\hline Koroneiki & $0.55 \pm 0.05 \mathrm{c}$ & $21.60 \pm 1.17 \mathrm{~b}$ & $1.88 \pm 0.10 \mathrm{c}$ & $0.22 \pm 0.01 \mathrm{a}$ \\
\hline Coefficient of variation (\%) & 3.0 & 5.6 & 2.5 & 6.7 \\
\hline
\end{tabular}

${ }^{(1)}$ Means followed by equal letters, in the column, do not differ by Tukey's test, at $5 \%$ probability. $\mathrm{K}_{232}$ and $\mathrm{K}_{270}$, specific absortion measured at 232 and $270 \mathrm{~nm}$, respectively. $\mathrm{n}=3$.

Table 2. Mean \pm standard deviation of bioactive compounds of olive (Olea europaea) oils from Arbequina, Coratina, Frantoio, and Koroneiki cultivars ${ }^{(1)}$.

\begin{tabular}{|c|c|c|c|c|c|c|}
\hline Cultivar & $\begin{array}{c}\beta+\gamma \text {-tocopherol } \\
\left(\mathrm{mg} \mathrm{kg}^{-1}\right)\end{array}$ & $\begin{array}{c}\alpha \text {-tocopherol } \\
\left(\mathrm{mg} \mathrm{kg}^{-1}\right)\end{array}$ & $\begin{array}{c}\delta \text {-tocopherol } \\
\left(\mathrm{mg} \mathrm{kg}^{-1}\right)\end{array}$ & $\begin{array}{l}\text { Phenolic compounds } \\
\left(\mathrm{mg} \mathrm{kg}^{-1} \text { gallic acid) }\right.\end{array}$ & $\begin{array}{c}\text { Carotenoids } \\
\text { (mg kg-1 } \beta \text {-carotene) }\end{array}$ & $\begin{array}{l}\text { Chlorophyll } \\
\left(\mathrm{mg} \mathrm{kg}^{-1}\right)\end{array}$ \\
\hline Arbequina & $7.50 \pm 0.01 \mathrm{~d}$ & $219.98 \pm 8.84 \mathrm{c}$ & $4.10 \pm 0.13 b$ & $651.74 \pm 6.90 \mathrm{~b}$ & $3.97 \pm 0.01 \mathrm{c}$ & $0.84 \pm 0.02 \mathrm{c}$ \\
\hline Coratina & $22.52 \pm 0.41 \mathrm{a}$ & $410.31 \pm 6.27 \mathrm{a}$ & $5.01 \pm 0.03 \mathrm{a}$ & $1,725.53 \pm 4.27 \mathrm{a}$ & $9.39 \pm 0.06 \mathrm{a}$ & $1.94 \pm 0.01 \mathrm{a}$ \\
\hline Frantoio & $8.92 \pm 0.12 \mathrm{c}$ & $181.77 \pm 3.47 \mathrm{~d}$ & $1.98 \pm 0.05 \mathrm{c}$ & $468.06 \pm 2.91 \mathrm{c}$ & $3.93 \pm 0.04 \mathrm{c}$ & $0.53 \pm 0.02 \mathrm{~d}$ \\
\hline Koroneiki & $10.93 \pm 0.29 b$ & $285.64 \pm 3.62 b$ & $1.85 \pm 0.05 \mathrm{c}$ & $437.18 \pm 3.19 \mathrm{~d}$ & $4.75 \pm 0.02 b$ & $0.90 \pm 0.01 \mathrm{~b}$ \\
\hline CV (\%) & 2.1 & 2.2 & 2.4 & 0.6 & 0.7 & 1.6 \\
\hline
\end{tabular}

${ }^{(1)}$ Means followed by equal letters, in the column, do not differ by Tukey's test, at $5 \%$ probability. CV, coefficient of variation. $\mathrm{n}=3$. 
content (Allouche et al., 2007; Gambacorta et al., 2010; Mansouri et al., 2014).

Regarding phenolic compound content, olive oil from the Coratina cultivar presented higher values than those of the other samples. Possibly the cultivar, fruit maturation index, and storage at ambient or refrigerated temperatures were responsible for the different levels observed in this study. Phenolic compounds also contribute to the peculiar aroma and flavor of olive oil, which are believed to significantly enhance oxidative stability due to their antioxidant properties (Allouche et al., 2007).

The oil from the Coratina cultivar stood out from the others due to this higher pigment content. Confirming this result, Aparicio-Ruíz et al. (2009) reported the $\beta$-carotene levels for the oils from the Coratina (4.04 and $5.41 \mathrm{mg} \mathrm{kg}^{-1}$ ), Frantoio (4.03 and $4.80 \mathrm{mg} \mathrm{kg}^{-1}$ ), and
Koroneiki (3.89 and $6.26 \mathrm{mg} \mathrm{kg}^{-1}$ ) cultivars close to those found in the olive cultivars from Southern Brazil.

Chlorophylls act as pro-oxidants in the presence of light; thus, variations in their oil contents, together with inadequate storage conditions, may affect the shelf life of the product (Bengana et al., 2013). According to the literature, the centrifugation process, which was used to obtain the Brazilian olive oils, produces high losses of pigments in relation to the pressing process used in other countries (Torres \& Maestri, 2006). This may explain in part the lower content of pigments found in Brazilian olive oils.

As expected, it was verified that the major fatty acids were oleic, palmitic, and linoleic (Table 3). The oleic fatty acid was the most representative in all samples, with higher content in olive oil from the Koroneiki cultivar $(76.5 \%)$ and lower content in olive oil from

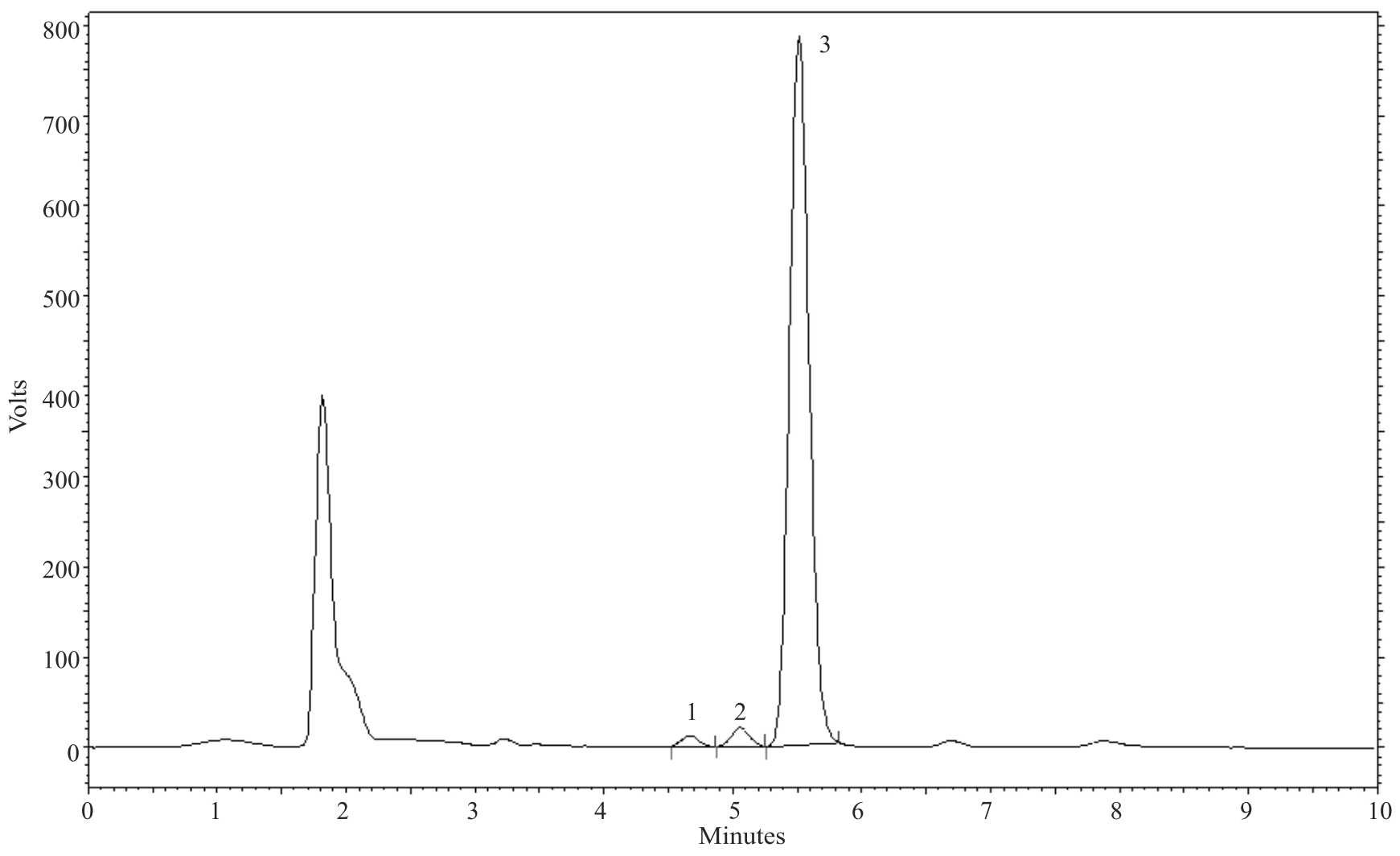

Figure 1. Typical chromatogram of $\delta-, \beta+\gamma-$, and $\alpha$-tocopherols separation of olive (Olea europaea) oil from the Arbequina cultivar by high-performance liquid chromatography using reverse phase RP-18CLS-ODS column and fluorescence detector, excitation at $290 \mathrm{~nm}$, and emission at $330 \mathrm{~nm}$. The peaks correspond to: $1, \delta$-tocopherol; $2, \beta+\gamma$-tocopherol, and 3, $\alpha$-tocopherol. 
Arbequina (59.2\%). These results are in alignment with the values recommended by the Brazilian legislation (Brasil, 2012; IOOC, 2012). Dabbou et al. (2010) reported, respectively, 61.4 and $76.0 \%$ for oleic acid in olive oil from the Arbequina and Koroneiki cultivars grown in Southern Tunisia. Daskalaki et al. (2009) found values from 75.1 to $78.5 \%$ for olive oil from the Koroneiki cultivar produced in Greece. Therefore, depending on the cultivar and the origin region, the relative percentage of the fatty acids varies.

Although the Arbequina cultivar is easily adaptable to the Brazilian soil and is well indicated for olive oil production, it is disadvantageous because it provides a oil with lower levels of oleic acid, which partially contributes to its lower stability (Mello \& Pinheiro, 2012). In the present study, the oil of this cultivar showed the highest content of saturated fatty acid; the palmitic acid content was the highest (18.5\%), close to the maximum value of $20 \%$ established by Brasil (2012) and IOOC (2012) (Figure 2).

The oils from the Frantoio and Arbequina cultivars stood out for total linoleic acid content, adding up to 14.8 and $16.6 \%$, respectively. However, it is known that oil stability to lipid oxidation is directly correlated with the number of double bonds present in the chain, which are susceptible to oxidation (Yun \& Surh, 2012). Furthermore, the essential compound group represented by omega- 6 fatty acids, precursor for arachidonic acid (C 20:4), and omega-3 fatty acids, precursor for both eicosapentaenoic acid EPA (C 20:5), and docosahexaenoic DHA (C 22:6) are related to the prevention of cardiovascular diseases, contributing to the metabolism regulation of low-density lipoprotein (LDL) (Dolinsky, 2009).

In addition to the palmitic, palmitoleic, stearic, oleic, linoleic, and linolenic fatty acids (Table 3), the following fatty acids were also observed, but in small amounts $(<0.5 \%)$ : myristic (C 14:0), margaric (C 17:0), margaroleic (C 17:1), arachidic (C 20:0), gadoneic ( C 20:1), behenic (C 22:0), and lignoceric (C 24:0). The fatty acid content found in the present study are in alignment with those recommended by Brasil (2012) and IOOC (2012).

Differences in oxidative stability were verified between samples, and greater stability was observed for the olive oil from the Coratina cultivar (Table 3). Lower peroxide, acidity, and polyunsaturated fatty acid ratio, as well as higher contents of bioactive compounds, may have positively affected the oxidative stability of this olive oil.

These results corroborate those presented by Ramalho \& Jorge (2006), who evaluated the oxidative stability of soy oil by Rancimat at $110^{\circ} \mathrm{C}$. By adding the antioxidants $\alpha$-tocopherol and rosemary extract to the oils, the authors demonstrated their protective effect on oxidation. Oils with higher oxidative stability also showed higher $\alpha$-tocopherol contents.

A high positive correlation coefficient $(\mathrm{r}=0.99$, $\mathrm{p}<0.0001)$ was observed for carotenoids and $(\gamma+\beta)$ tocopherol contents, confirming that an increase in carotenoids can lead to an increase in $(\gamma+\beta)$ tocopherol (Table 4). Positive correlations were also

Table 3. Mean and standard deviations (SD) of main fatty acids and oxidative stability of olive (Olea europaea) oils from Arbequina, Coratina, Frantoio, and Koroneiki cultivars ${ }^{(1)}$.

\begin{tabular}{|c|c|c|c|c|c|c|c|c|c|c|c|c|}
\hline Cultivar & C 16:0 & C $16: 1$ & C 18:0 & C 18:1 & C 18:2 & C $18: 3$ & C 20:0 & C 20:1 & C 24:0 & $\begin{array}{c}\text { Total } \\
\text { saturated }\end{array}$ & $\begin{array}{c}\text { Total } \\
\text { unsaturated }\end{array}$ & $\begin{array}{c}\text { Oxidative } \\
\text { stability } \\
\text { (h) }\end{array}$ \\
\hline Arbequina & $18.51 \mathrm{a}$ & $3.34 \mathrm{a}$ & $1.20 \mathrm{~b}$ & $59.15 d$ & $15.79 a$ & $0.76 \mathrm{c}$ & $0.39 b$ & $0.27 \mathrm{~b}$ & $0.18 \mathrm{~b}$ & $20.51 \mathrm{a}$ & $79.49 c$ & $3.22 \mathrm{~d}$ \\
\hline $\mathrm{SD}$ & 0.15 & 0.10 & 0.03 & 0.10 & 0.07 & 0.03 & 0.02 & 0.00 & 0.00 & 0.20 & 0.20 & 0.06 \\
\hline Coratina & $14.19 \mathrm{c}$ & $0.58 \mathrm{c}$ & $1.66 \mathrm{~b}$ & $72.11 b$ & $9.19 \mathrm{c}$ & $1.00 \mathrm{a}$ & $0.39 b$ & $0.32 \mathrm{a}$ & $0.21 \mathrm{a}$ & $16.36 \mathrm{c}$ & $83.64 a$ & $20.47 \mathrm{a}$ \\
\hline $\mathrm{SD}$ & 0.06 & 0.00 & 0.06 & 0.29 & 0.24 & 0.00 & 0.02 & 0.02 & 0.00 & 0.01 & 0.01 & 0.24 \\
\hline Frantoio & $15.12 b$ & $1.34 \mathrm{~b}$ & $1.59 \mathrm{~b}$ & $66.11 \mathrm{c}$ & $13.94 b$ & $0.85 b$ & $0.32 \mathrm{c}$ & $0.31 \mathrm{a}$ & $0.10 \mathrm{~d}$ & $17.21 \mathrm{~b}$ & $82.79 b$ & $5.64 \mathrm{c}$ \\
\hline $\mathrm{SD}$ & 0.01 & 0.01 & 0.02 & 0.01 & 0.01 & 0.03 & 0.00 & 0.00 & 0.00 & 0.03 & 0.03 & 0.15 \\
\hline Koroneiki & $12.82 \mathrm{~d}$ & $0.75 \mathrm{c}$ & $2.49 \mathrm{a}$ & $76.47 \mathrm{a}$ & $5.52 \mathrm{~d}$ & $0.75 \mathrm{c}$ & $0.46 a$ & $0.32 \mathrm{a}$ & $0.13 \mathrm{c}$ & $16.07 \mathrm{c}$ & $83.93 \mathrm{a}$ & $11.81 \mathrm{~b}$ \\
\hline $\mathrm{SD}$ & 0.06 & 0.00 & 0.23 & 0.11 & 0.03 & 0.00 & 0.00 & 0.00 & 0.00 & 0.16 & 0.16 & 0.06 \\
\hline CV (\%) & 0.6 & 3.3 & 6.8 & 0.2 & 1.1 & 2.7 & 3.9 & 3.8 & 4.5 & 0.7 & 0.1 & 1.4 \\
\hline
\end{tabular}

${ }^{(1)}$ Means followed by equal letters, in the column, do not differ by Tukey's test, at 5\% probability. CV, coefficient of variation mean of three replicates. 


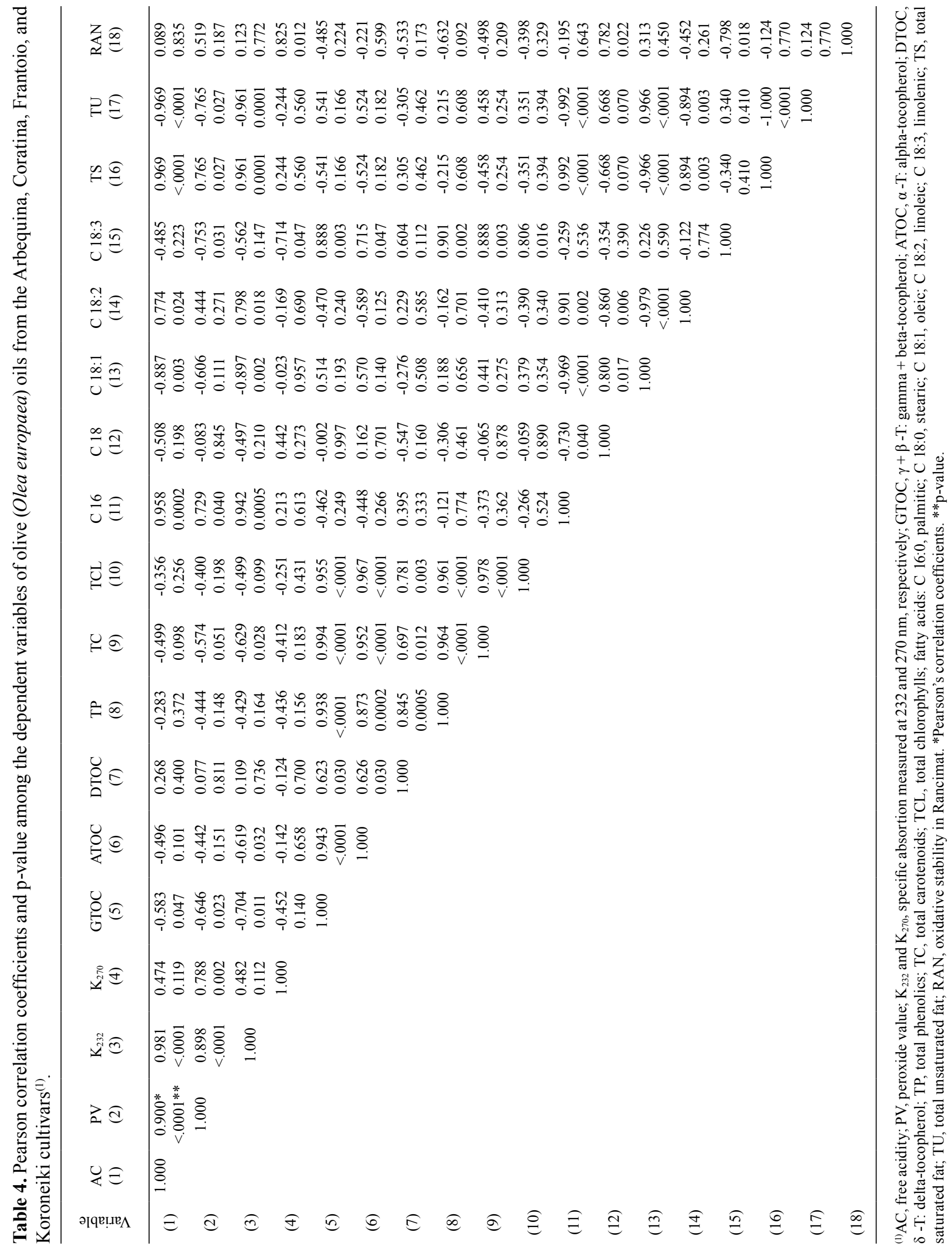




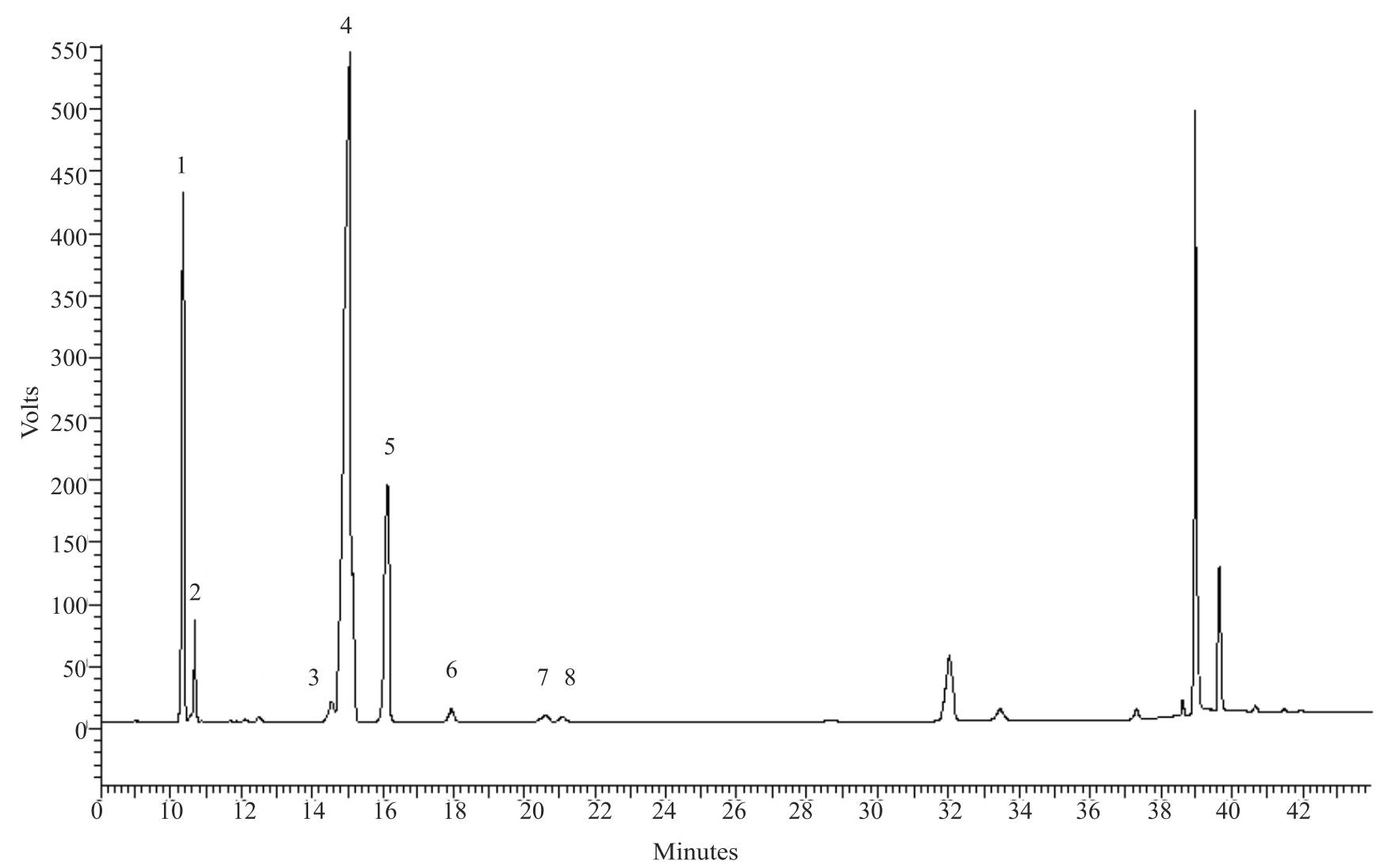

Figure 2. Typical chromatogram of fatty acid separation of olive (Olea europaea) oil from the Arbequina cultivar, using a gas chromatograph, equipped with a FID detector. The peaks correspond to the fatty acids: 1, palmitic; 2, palmitoleic; 3 , stearic; 4, oleic; 5, linoleic; 6, linolenic; 7, arachidic; and 8, gadoleic.

observed between the phenolic compounds and tocopherols $(\gamma+\beta)$-tocopherol; and $\alpha$-tocopherol and $\delta$-tocopherol. A high positive correlation was found between chlorophyll content and $(\gamma+\beta)$-tocopherol; and $\alpha$-tocopherol and $\delta$-tocopherol.

The phenolic compounds, carotenoids, tocopherol, and fatty acid profiles contributed positively to oil stability. Olive oil from the Coratina cultivar presented higher contents of bioactive compounds and, consequently, greater oxidative stability. However, the oxidation reaction occurs through several mechanisms, which makes its elucidation very complex.

The production of olive oil in Brazil is still small, but of great importance for a boost in the country's olive crop. Thus, this study provides data on oils obtained from the most expressive cultivars in the southern region of Rio Grande do Sul, Brazil. In this scenario, many possibilities open up, and there is great motivation for further investigative research.

\section{Conclusions}

1. The olive (Olea europaea) oils from the Coratina and Frantoio cultivars produced in Southern Brazil are classified as extra-virgin, in alignment with the quality parameters established for the product.

2. Olive oil from the Coratina cultivar presents greater oxidative stability due to a higher content of phenolic compounds, carotenoids, and tocopherols.

\section{Acknowledgments}

To Coordenação de Aperfeiçoamento de Pessoal de Nível Superior (Capes) and to Fundação de Amparo à Pesquisa do Estado do Rio Grande do Sul (Fapergs), for financial support. 


\section{References}

ALLALOUT,A.; KRICHENÉ,D.; METHENNI,K.; TAAMALLI, A.; OUESLATI, I.; DAOUD, D.; ZARROUK, M. Characterization of virgin olive oil from super intensive spanish and greek varieties grown in northern Tunisia. Scientia Horticulturae, v.120, p.7783, 2009. DOI: 10.1016/j.scienta.2008.10.006.

ALLOUCHE, Y.; JIMÉNEZ, A.; GAFORIO, J.J.; UCEDA, M.; BELTRÁN, G. How heating affects extra virgin olive oil quality indexes and chemical composition. Journal of Agricultural and Food Chemistry, v.55, p.9646-9654, 2007. DOI: 10.1021/ jf070628u.

APARÍCIO-RUÍZ, R.; GANDUL-ROJAS, B.; ROCA, M. Pigment profile in non-spanish olive varieties (Olea europae L. var. Coratina, Frantoio and Koroneiki. Journal of Agricultural and Food Chemistry, v.57, p.10831-10836, 2009. DOI: 10.1021/ jf9027393.

BENGANA, M.; BAKHOUCHE, A.; LOZANO-SÁNCHEZ, J.; AMIR, Y.; YOUYOU, A.; SEGURA-CARRETERO, A.; FERNÁNDEZ-GUTIÉRREZ, A. Influence of olive ripeness on chemical properties and phenolic composition of Chemlal extravirgin olive oil. Food Research International, v.54, p.1868-1875, 2013. DOI: 10.1016/j.foodres.2013.08.037.

BRASIL. Ministério da Agricultura, Pecuária e Abastecimento. Instrução Normativa $\mathrm{n}^{\circ} 1$, de 30 de janeiro de 2012. [Estabelece o Regulamento Técnico do Azeite de Oliva e do Óleo de Bagaço de Oliva e os limites de tolerância]. Diário Oficial da União, 1 fev. 2012. Seção 1, p.5-8. Available at: $<$ http://pesquisa.in.gov.br/imprensa/jsp/visualiza/index. jsp?data $=01 / 02 / 2012 \&$ jornal $=1 \&$ pagina $=5 \&$ totalArquivos $=112>$. Accessed on: Oct. 32017.

CARDOSO, L.G.V.; BARCELOS, M. de F.P.; OLIVEIRA, A.F. de; PEREIRA, J. de A.R.; ABREU, W.C. de; PIMENTEL, F. de A.; CARDOSO, M. das G.; PEREIRA, M.C. de A. Características físico-químicas e perfil de ácidos graxos de azeites obtidos de diferentes variedades de oliveiras introduzidas no Sul de Minas Gerais - Brasil. Semina: Ciências Agrárias, v.31, p.127-136, 2010.

CEN. European Committee for Standardization. EN 14112:2003: Fat and Oil Derivatives: Fatty Acid Methyl Esters (FAME): determination of oxidative stability (accelerated oxidation test). Brussels, 2003.

CICERALE, S.; CONLAN, X.A.; BARNETT, N.W.; KEAST, R.S.J. Storage of extra virgin olive oil and its effect on the biological activity and concentration of oleocanthal. Food Research International, v.50, p.597-602, 2013. DOI: 10.1016/j. foodres.2011.03.046.

COUTINHO, E.F.; RIBEIRO, F.C.; CAPPELLARO, T.H. (Ed.). Cultivo de oliveira (Olea europaea L.). Pelotas: Embrapa Clima Temperado, 2009. 126p. (Embrapa Clima Temperado. Sistema de produção, 16).

DABBOU, S.; BRAHMI, F.; TAAMALI, A.; ISSAOUI, M.; OUNI, Y.; BRAHAM, M.; ZARROUK, M.; HAMMAMI, M. Extra virgin olive oil components and oxidative stability from olives grow in
Tunisia. Journal of the American Oil Chemists Society, v.87, p.1199-1209, 2010. DOI: 10.1007/s11746-010-1600-3.

DASKALAKI，D.; KEFI，G.; KOTSIOU, K.; TASIOULAMARGARI, M. Evaluation of phenolic compounds degradation in virgin olive oil during storage and heating. Journal of Food and Nutrition Research, v.48, p.31-41, 2009.

DOLINSKY, M. (Org.). Nutrição funcional. São Paulo: Roca, 2009. 204p.

FADDA, C.; DEL CARO, A.; SANGUINETTI, A.M.; URGEGHE, P.P.; VACCA, V.; ARCA, P.P.; PIGA, A. Changes during storage of quality parameters and in vitro antioxidant activity of extra virgin monovarietal oils obtained with two extraction technologies. Food Chemistry, v.134, p.1542-1548, 2012. DOI: 10.1016/j. foodchem.2012.03.076.

FIRESTONE, D. (Ed.). Official Methods and Recommended Practices of the American Oil Chemists Society. $5^{\text {th }}$ ed. Champaign: AOCS, 1998. 2v.

FREGAPANE, G.; SALVADOR, M.D. Production of superior quality extra virgin olive oil modulating the content and profile of its minor components. Food Research International, v.54, p.1.907-1914, 2013. DOI: 10.1016/j.foodres.2013.04.022.

GAMBACORTA, G.; FACCIA, M.; PREVITALI, M.A.; PATI, S.; LA NOTTE, E.; BAIANO, A. Effects of olive maturation and stoning on quality indices and antioxidant Content of extra virgin oils (cv. Coratina) during Storage. Journal of Food Science, v.75, p.229-235, 2010. DOI: 10.1111/j.1750-3841.2010.01516.x.

HARTMAN, L.; LAGO, R.C.A. Rapid preparation of fatty acid methyl esters from lipids. Laboratory Practice, v.22, p.475-477, 1973.

IOOC. International Olive Oil Council. Method of analysis: spectrophotometric investigation in the ultraviolet. Madri, 2010. 11p. COI/T20/Doc. no. 19/Rev. 3.

IOOC. International Olive Oil Council. Trade standard applying to olive oils and olive-pomace oils. Madri, 2012. 16p. COI/T.15/ NC No 3/Rev. 7.

KÖPPEN, W.; GEIGER, R. Klimate der Erde. Gotha: Verlag Justus Perthes, 1928. Wall-map, 150 x $200 \mathrm{~cm}$.

KRICHENE, D.; ALLALOUT, A.; MANCEBO-CAMPOS, V.; SALVADOR, M.D.; ZARROUK, M.; FREGAPANE, G. Stability of virgin olive oil and behaviour of its natural antioxidants under medium temperature accelerated storage conditions. Food Chemistry, v.121, p.171-177, 2010. DOI: 10.1016/j. foodchem.2009.12.026.

MANSOURI, F.; BEN MOUMEN, A.; HOUMY, N.; RICHARD, G.; FAUCONNIER, M.L.; SINDI, M.; SERGHINI-CAID, H.; ELAMRANI, A. Evaluación de la estabilidad oxidativa de los aceites de oliva obtenidos a partir de la mezcla de aceite "Arbequina" con otros aceites de oliva monovarietales. OLIVAE, n.120, p.23-30, 2014.

MELLO, L.D.; PINHEIRO, M.F. Aspectos físico-químicos de azeites de oliva e de folhas de oliveira provenientes de cultivares do RS, Brasil. Alimentos e Nutrição, v.23, p.537-548, 2012.

MONTEDORO, G.; SERVILI, M.; BALDIOLI, M.; MINIATI, E. Simple and hydrolyzable phenolic compounds in virgin olive oil. 1. Their extraction, separation, and quantitative and 
semiquantitative evaluation by HPLC. Journal of Agricultural and Food Chemistry, v.40, p.1571-1576, 1992. DOI: 10.1021/ jf00021a019.

PESTANA, V.R.; ZAMBIAZI, R.C.; MENDONÇA, C.R.B.; BRUSCATTO, M.H.; LERMA-GARCÍA, M.J.; RAMISRAMOS, G. Quality changes and Tocopherols and $\gamma$-Orizanol concentrations in rice bran oil during the refining process. Journal of the American Oil Chemists' Society, v.85, p.10131019, 2008. DOI: 10.1007/s11746-008-1300-4.

RAMALHO, V.C.; JORGE, N. Atividade antioxidante do $\alpha$-tocoferol e do extrato de alecrim em óleo de soja purificado.

Revista do Instituto Adolfo Lutz, v.65, p.15-20, 2006.

RODRIGUES-AMAYA, D.B. A guide to carotenoid analysis in foods. Washington: ILSI, 2001. 64p.

SANTOS, H.G. dos; JACOMINE, P.K.T.; ANJOS, L.H.C. dos; OLIVEIRA, V.A. de; OLIVEIRA, J.B. de; COELHO, M.R.; LUMBRERAS, J.F.; CUNHA, T.J.F. (Ed.). Sistema brasileiro de classificação de solos. 2.ed. Rio de Janeiro: Embrapa Solos, 2006. $412 \mathrm{p}$.
SERVILI, M. Her majesty the coratina olive. Available at: $<$ http://www.olioofficina.net/knowledge/oil/her-majesty-thecoratina-olive.htm>. Accessed on: Feb. 152015.

SILVA, F.A.M.; BORGES, M.F.M.; FERREIRA, M.A. Métodos para avaliação do grau de oxidação lipídica e capacidade antioxidante. Química Nova, v.22, p.94-103, 1999. DOI: 10.1590/ S0100-40421999000100016.

TORRES, M.M.; MAESTRI, D.M. Chemical composition of arbequina virgin olive oil in relation to extraction and storage conditions. Journal of the Science of Food and Agriculture, v.86, p.2311-2317, 2006. DOI: 10.1002/jsfa.2614.

YUN, J.-M.; SURH, J.H. Fatty acid composition as a predictor for the oxidation stability of Korean vegetable oils with or without induced oxidative stress. Preventive Nutrition and Food Science, v.17, p.158-165, 2012. DOI: 10.3746/pnf.2012.17.2.158.

ZAMBIAZI, R.Z. The role of endogenous lipid components on vegetable oil stability. 1997. 304p. Thesis (Doctor) - University of Manitoba, Winnipeg.

Received on February 22, 2016 and accepted on May 15, 2017 